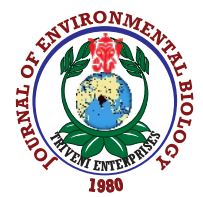

\title{
Phytoremediation potential of some abundantly growing indigenous herbs of crude oil contaminated sites
}

\author{
S. Akram and H. Deka* \\ Department of Botany, Gauhati University, Guwahati-781 014, India \\ *Corresponding Author Email : hemendeka@gauhati.ac.in
}

\section{Abstract}

Aim: To study the total oil and grease (TOGs) removal potential of three abundant herb species of crude oil contaminated sites, namely Xanthium strumarium (L.), Ageratum conyzoides (L.) and Polygonum hydropiper (L.) from oil contaminated soils.

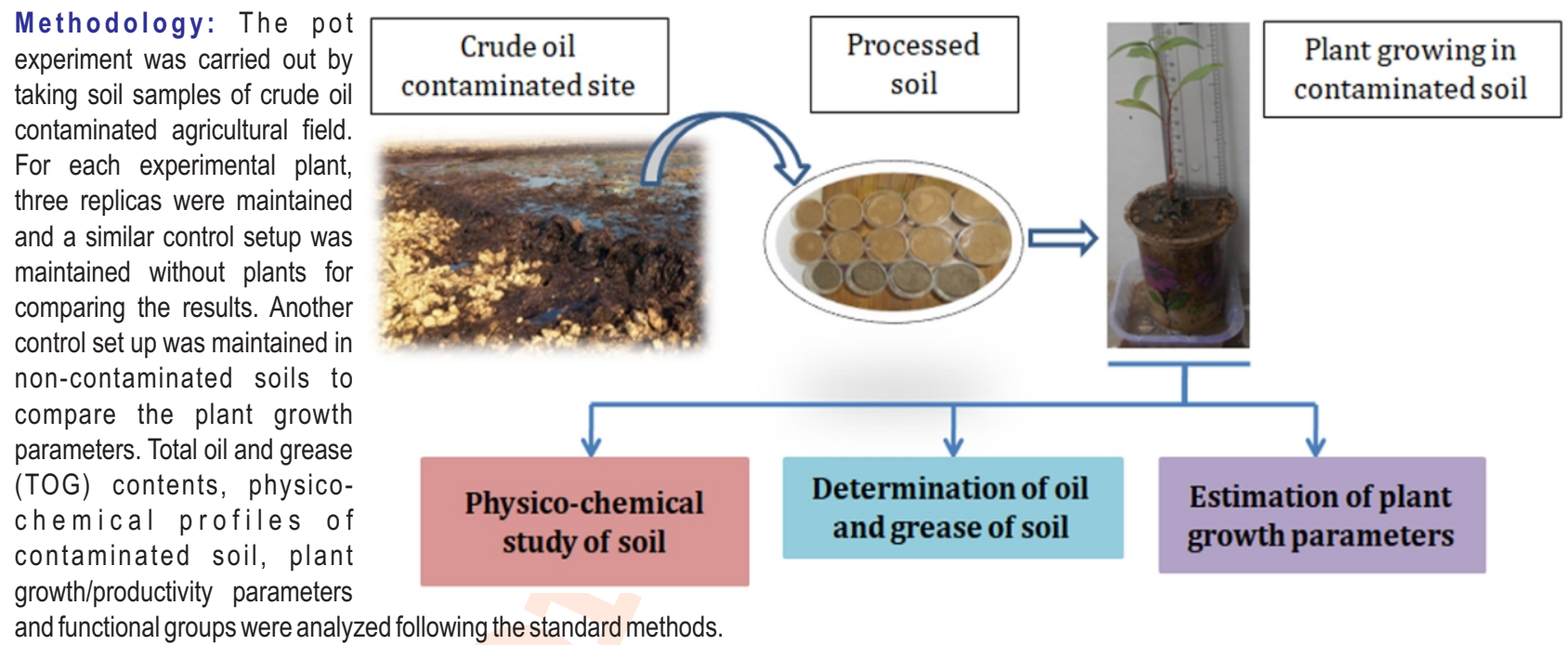

Results: The results showed that total oil and grease (TOG) contents decreased significantly after treatments by plants against the initial level and control. Plant height, number of leaves, chlorophyll contents and biomass were found to be lower in all the three plant species that were grown in contaminated soil as against the control treatment. The improved physico-chemical profiles of contaminated soil samples after treatment indicated the positive effect of plants in treated soil samples. FTIR data revealed difference in peak intensities and the presence of petroleum hydrocarbons in plants that were grown in oil-contaminated soils.

Interpretation: The herb species Xanthium strumarium, Ageratum conyzoides and Polygonum hydropiper showed the potential for removal of hydrocarbons from crude oil contaminated soil.

Key words: Crude oil, Hydrocarbons, Indigenous herbs, Phytoremediation

How to cite : Akram, S. and H. Deka: Phytoremediation potential of some abundantly growing indigenous herbs of crude oil contaminated sites. J. Environ. Biol., 42, 51-61 (2021). 


\section{Introduction}

Crude oil pollution is a global problem from oil production industries (Markel et al., 2004). In oil producing states of India, the crude oil associated burden is a perennial problem since the inception of oil industries. Again, in Assam most of the oil industries are situated near the agricultural field as well as in the periphery of human settlements. Contamination from crude oil takes place in various ways such as during oil extraction, storage, transportation, refining process of crude oil etc. All these activities ultimately pollute the nearby habitat (Urum et al., 2006; Lai et al., 2009). Continuous release of crude oil associated pollutants exert physico-chemical, biological and structural changes in soil systems and make them unfit for cultivation (Wei et al., 2019). It has been reported that crude oil pollutants such as heavy metals (HMs) and polycyclic aromatic hydrocarbons (PAHs) are carcinogenic and mutagenic (Das and Chandran, 2011) which not only impose adverse affects on soil microbes but also other organisms, including human beings (Scott and Nelson, 2004; Anyika et al., 2015). Considering the fact, it is necessary to remove the crude oil pollutants from soil.

Phytoremediation is a promising, cost effective and eco-friendly technique for remediation of crude oil polluted soils. It has been reported that plants are effective in degradation, transformation, assimilation, metabolism and detoxification of hazardous pollutants from soils (Cai et al., 2010). The efficacy of plants for removal of crude oil pollutants has already been established by several workers around the globe (Han et al., 2016; Cheng et al., 2017). For example, some plants such as tall fescue, fire phoenix and maize have also been used for remediation of crude oil contaminated soil in recent past (Liu et al. 2014a,b; Liao et al. 2016). Nevertheless, the selection of plant species is crucial in phytoremediation, and even in most cases their success is site specific (Euliss et al., 2007; Kirkpatrick et al., 2006) and, therefore, use of indigenous plants of the polluted sites are always preferred.

Moreover, considering the better adaptability due to fibrous root systems; herbaceous and annual plants has been reported to be more successful in remediation of soils contaminated by crude oil (Hutchinson et al., 2001: Kechavarzi et al., 2007; Basumatary et al., 2012a, b; Ikeura et al., 2016). It has been reported that native herb species of crude oil polluted soils of Assam such as Cyperus rotandus; Cyperus brevifolius; Axonopus compresus are effective in removal of total oil grease contents from contaminated soils (Basumatary et al., 2012a,b; Bordoloi et al., 2012). Nonetheless, further investigation on phytoremediation potential of indigenous herbaceous community of crude oil polluted sites is needed in order to end up the lacuna of phytotechnology for remediation of polluted soils.

The herb species Xanthium strumarium L., Ageratum conyzoides L. and Polygonum hydropiper (L.) are found to grow abundantly in the crude oil polluted agro-ecosystems of Assam, India. Therefore, these herb species may possess some adaptive advantage to withstand with the adverse situations posed due to crude oil pollution. The aim of the present investigation is to study the total oil and grease (TOG) removal potential of Xanthium strumarium, Ageratum conyzoides and Polygonum hydropiper in crude oil polluted soils.

\section{Materials and Methods}

Collection of soil samples and physico-chemical analyses: The Lakowa oil field $\left(25^{\circ} 01^{\prime} \mathrm{NL}, 94^{\circ} 50^{\prime} \mathrm{EL}\right)$ of Assam, India was selected as study site. The Lakwa oil field is under the operation of Oil and Natural Gas Commission (ONGC), India. The experimental soil samples were collected at a depth of $0-20 \mathrm{~cm}$ from the oil contaminated agricultural fields near the GGS4 (Group Gathering Station) where crude oil is stored before sending to the refineries. The collected soil samples were shade dried, debris were removed and finally grinded into fine particles for experimental use. The physico-chemical parameters of the collected samples were studied to understand the deterioration in soil conditions and included analysis of $\mathrm{pH}$, conductivity, water holding capacity, total organic carbon, total Kjeldhal nitrogen available phosphorus, total potassium and finally total oil and grease contents. The soil $\mathrm{pH}$ and conductivity were measured in 1:5 soil suspensions using digital $\mathrm{pH}$ (Universal 6331) and conductivity meter (Systronics 2485).

The water holding capacity of the soil samples were determined by the methods of Piper (Singh et al., 1991). Total organic carbon content level was measured by Walkey and Black titration method (Walkey and Black, 1974). Total Kjeldhal nitrogen content of the soil was estimated by microkjeldhal method (Jackson, 1973). Available phosphorus was estimated spectrophotometrically (Shimadzu UV1601) following the stannous chloride method (APHA, 1998). Total potassium content was determined by the acid digestion method using a flame photometer with standard solution (APHA, 2017). Total oil and grease content of the soil samples were extracted with dichloromethane in soxhlet extractor (Martin Jr et al.1991) and measured gravimetrically (Villalobos et al., 2008).

Experimental plants: Xanthium strumarium L., Ageratum conyzoides L. and Polygonum hydropiper L. were selected as experimental plants. These three species were found abundantly in the crude oil contaminated sites of Assam, India. However, for the experimental purpose plant seeds were collected locally and grown in pots separately. The same aged seedlings were selected for experimental trials.

Experimental setup: The experiment was carried out in plastic pots in net house. The duration of the experiment was fixed for 60 days. In each pot, equal amount of contaminated soil $(200 \mathrm{gm})$ was taken, mixed properly after watering and left for three days to settle down. Then a single plant seedling was introduced to the respective pots. Separate set up was maintained for each plant species. A similar control set up was also maintained without plants for comparison of the results. Another control set up was also maintained in non-contaminated soil to compare the plant growth parameters. In each case, three replicas were taken for statistical analysis of the results. The physico-chemical properties along with TOGs of the contaminated soil were analyzed before introduction of the plants as well as after completion of the experimental trial following the methods as mentioned in collection of soil samples and physico-chemical analysis section. Plant growth parameters that includes morphological characters such as shoot length, root length and number of leaves, leaf area index (LAl), biomass values and chlorophyll contents were analyzed at the beginning and by end of the experimental trials following the standard methods.

FTIR Analysis: FTIR Spectroscopy was conducted by following the KBr palate method. Shoot portion of each plant species were dried and grind separated in mortar and pestle. Powder of the stems was then mixed with $\mathrm{KBr}$ in 1:80 ratio and pellets were prepared by establishing pressure of $10 \mathrm{~kg} \mathrm{~cm}^{2}$ for about $1 \mathrm{~min}$. Spectra ranging between wave numbers 4500 and $400 \mathrm{~cm}^{-1}$ were recorded with Fourier transform infrared spectroscopy (IR Affinity1). Functional groups were identified and interpreted (Pavia et al., 2008)

Statistical Analyses: SPSS software (2018 version) was used for statistical analysis. The significant difference in values of 
physico-chemical properties of the soil samples, plant growth parameters were determined by pair-sample t-test, One-way ANOVAand LSD test.

\section{Results and Discussion}

The results of TOGs dissipation is presented in Fig. 1. The results revealed that there was significant reduction in TOGs level after treatment by each plant species. The initial TOG contents of contaminated soil was $197 \mathrm{gm} \mathrm{kg}^{-1}$ which reduced significantly to $54 \mathrm{gm} \mathrm{kg}^{-1}, 78 \mathrm{gm} \mathrm{kg}^{-1}$ and $69 \mathrm{gm} \mathrm{kg}^{-1}$ after the treatment with Ageratum conyzoides, Polygonum hydropiper and Xanthium strumarium respectively. Thus, reduction in TOG levels over the initial value was $72 \%, 60 \%$, and $64 \%$ for Ageratum conyzoides, Polygonum hydropiper and Xanthium strumarium, respectively. The present findings corroborates with the results of Peng et al. (2009), who reported about $63 \%$ reduction in oil content by Mirabilis jalapa in the crude oil contaminated soil. Similarly, Ikhajiagbe et al. (2017) reported upto $46 \%$ reduction in TOG contents from oil contaminated soil employing Eleusine indica. Degradation of petroleum hydrocarbon was found higher by fescue, sorghum, cowpea, alfalfa and black rush plants (Merkl et al., 2004).

On the other hand in the control treatment, a $16 \%$ dissipation of TOG content was recorded which may be due to oil evaporation along with other natural and microbiological process (Chukwuma et al., 2019). The TOG dissipation percentage increased 4.5, 3.8 and 4 fold for Ageratum conyzoides, Polygonum hydropiper and Xanthium strumarium, respectively over control treatment may be attributed to the synergistic action of plants and microbes in the soil (Asemoloye et al., 2019). Although, correlation of rhizosphere microbial population with the studied herbs has not been presented in this investigation. It has already been established that of biodegradation significantly accelerates when there is rise in microbial population in the rhizosphere zone (Basumatary et al., 2012a). The results of the physico-chemical analysis are presented in Table 1. The results revealed that there were changes in the physico-chemical conditions of soil after treatment by the experimental plant species.

Soil $\mathrm{pH}$ indicates the soil health and availability of other nutrients for the plant. The crude oil contaminated soil sample was found to be acidic with a pH value of 4.27 at the beginning of experimental trials. The $\mathrm{pH}$ level in soil samples changes to 6.07 , 6.10 and 6.59, respectively, post treatment with Ageratum conyzoides, Polygonum hydropiper and Xanthium strumarium. This indicates that there was shifting of acidic condition of soil towards the near-neutral range. Oil contaminated soil are generally acidic in nature is due to the presence of toxic acids and pollutants (Barua et al., 2011; Oyem and Oyem, 2013; Basumatary et al., $2012 b$ ). The change in the acidic nature of oil contaminated soil after treatment by plants may be due to microbial action upon toxic acids/pollutants and uptake of pollutants by the treated plant species (Egharevba et al., 2017), although further planned study is required to prove this hypothesis.

The initial value of conductivity in the contaminated soil sample was found to be $0.08 \mathrm{mS} \mathrm{ds}^{-1}$. The conductivity values of the soil changed to $0.32,0.54$ and $0.69 \mathrm{mS} \mathrm{ds}^{-1}$ respectively, post treatment with Ageratum conyzoides, Polygonum hydropiper and Xanthium strumarium. The lower conductivity values of oil contaminated soil indicate the adverse effect of crude oil pollution. Non-polar nature of crude oil reduces ionic movement in the soil (Akpoveta et al., 2011; Osuji and Nwoye, 2007), there by reducing the conductivity. Increasing trends in soil conductivity of contaminated soil after plant treatment may be due to plantmicrobe interaction which ultimately degrades the oily layer, besides releasing some ions in soil system (Baruah et al., 2014).

The crude oil contaminated soil samples showed reduced level of water holding capacity (9.86) during the start of the experiment. Lower values of water holding capacity may be due to the hydrophobic nature of crude oil and the formation of oil coating over the soil surface. Similar findings were reported by Vara et al. (2012). After harvesting the plants, water holding capacity was found to be $29.3 \%, 26.6 \%$ and $25.43 \%$ for Ageratum conyzoides, Polygonum hydropiper and Xanthium strumarium, respectively. The enhanced value of water holding capacity may be due to reduction of total oil grease contents from the soil (Baruah etal., 2014). The water holding capacity of $25.04 \%$ or more is suitable for agricultural purpose (Baruah et al., 2013).

Initial level of total organic carbon in the oil contaminated soil sample was $18.75 \%$ whereas post plant treatment, the values decreased by $8.15 \%, 12.8 \%$ and $9.58 \%$, respectively, Polygonum hydropiper and Xanthium strumarium. Since crude oil contains

Table 1: Physico-chemical analysis of crude oil contaminated soils at the beginning and post plant treatment by Ageratum conyzoides, Polygonum hydropiperand Xanthium strumarium

\begin{tabular}{|c|c|c|c|c|c|}
\hline \multirow[t]{2}{*}{ Parameters } & \multicolumn{5}{|c|}{ Post plant treatments } \\
\hline & Initial & Control & A. conyzoides & P. hydropiper & X. strumarium \\
\hline $\mathrm{pH}$ & $4.27 \pm 0.1^{\mathrm{a}}$ & $4.69 \pm 0.24^{\mathrm{a}}$ & $6.07 \pm 0.9^{c}$ & $6.10 \pm 0.04^{d}$ & $6.59 \pm 0.15^{k}$ \\
\hline Conductivity (mS ds ${ }^{-1}$ ) & $0.08 \pm 0.007^{\mathrm{a}}$ & $0.09 \pm 0.003^{\mathrm{a}}$ & $0.32 \pm 0.009^{d}$ & $0.54 \pm 0.02^{b}$ & $0.69 \pm 0.12^{p}$ \\
\hline Water holding capacity (\%) & $10.78 \pm 1.1^{\mathrm{a}}$ & $9.86 \pm 0.7^{\mathrm{a}}$ & $29.3 \pm 1.2^{k}$ & $26.6 \pm 0.9^{b}$ & $25.43 \pm 0.9^{p}$ \\
\hline Total organic carbon (\%) & $17.11 \pm 1.1^{\mathrm{a}}$ & $18.75 \pm 1.2^{\mathrm{a}}$ & $8.15 \pm 0.5^{c}$ & $12.8 \pm 0.5^{b}$ & $9.58 \pm 0.87^{d}$ \\
\hline Total nitrogen $(\%)$ & $890 \pm 40^{\mathrm{a}}$ & $884.3 \pm 34^{a}$ & $503 \pm 10^{b}$ & $420 \pm 70^{\circ}$ & $390 \pm 30^{d}$ \\
\hline Available phosphorus $\left(\mathrm{mg} \mathrm{kg}^{-1}\right)$ & $30 \pm 1.7^{\mathrm{a}}$ & $28.7 \pm 2.3^{\mathrm{a}}$ & $23.4 \pm 3^{b}$ & $11 \pm 0.51^{\circ}$ & $8.6 \pm 2.1^{d}$ \\
\hline Total potassium $\left(\mathrm{mg} \mathrm{kg}^{-1}\right)$ & $272.56 \pm 8^{\mathrm{a}}$ & $266.9 \pm 8.6^{a}$ & $210.8 \pm 9^{b}$ & $220.03 \pm 5.9^{c}$ & $223.53 \pm 6.1^{\mathrm{d}}$ \\
\hline
\end{tabular}

Values are mean of three replicates $\pm S D$. Different letters in the same rows indicate significant differences in values among different treatments 
Table 2: Morphological changes in Ageratum conyzoides, Polygonum hydropiperand Xanthium strumarium after 60 days of experimental trials in control and crude oil contaminated soils

\begin{tabular}{|c|c|c|c|c|c|c|c|c|c|c|c|c|}
\hline \multicolumn{6}{|c|}{ Morphological parameters } & \multicolumn{7}{|c|}{ Plant species } \\
\hline & \multicolumn{4}{|c|}{ Ageratum conyzoides } & \multicolumn{4}{|c|}{ Polygonum hydropiper } & \multicolumn{4}{|c|}{ Xanthium strumarium } \\
\hline & \multicolumn{2}{|l|}{ Control } & \multicolumn{2}{|c|}{ Contaminated } & \multicolumn{2}{|l|}{ Control } & \multicolumn{2}{|c|}{ Contaminated } & \multicolumn{2}{|l|}{ Control } & \multicolumn{2}{|c|}{ Contaminated } \\
\hline & Initial & Final & Initial & Final & Initial & Final & Initial & Final & Initial & Final & Initial & Final \\
\hline $\begin{array}{l}\text { Shoot } \\
\text { length } \\
\text { (cm) }\end{array}$ & $5 \pm 0.4^{\mathrm{a}}$ & $18.7 \pm 1.1^{\mathrm{b}}$ & $5.3 \pm 0.3^{\mathrm{a}}$ & $10.3 \pm 0.5^{d}$ & $9.1 \pm 1.6^{e}$ & $21.5 \pm 2.1^{\dagger}$ & $9.1 \pm 1.7^{9}$ & $14.2 \pm 1.9^{\mathrm{h}}$ & $10.6 \pm 1.6$ & $19.1 \pm 4.4^{j}$ & $10.7 \pm 1.7^{p}$ & $12 \pm 3.1^{\mathrm{m}}$ \\
\hline $\begin{array}{l}\text { Root } \\
\text { length } \\
\text { (cm) }\end{array}$ & $3.5 \pm 0.3^{\mathrm{a}}$ & $4.9 \pm 0.4^{p}$ & $3.4 \pm 0.4^{\mathrm{a}}$ & $3.9 \pm 0.6^{k}$ & $3.2 \pm 0.7^{b}$ & $5.9 \pm 0.4^{9}$ & $3.2 \pm 0.7^{b}$ & $4.5 \pm 0.6^{d}$ & $3.2 \pm 0.7^{b}$ & $5.0 \pm 0.45^{x}$ & $3.3 \pm 0.8^{b}$ & $4.2 \pm 0.6^{2}$ \\
\hline $\begin{array}{l}\text { Number } \\
\text { of } \\
\text { leaves }\end{array}$ & $7.6 \pm 0.57^{\mathrm{a}}$ & $26.6 \pm 2.8^{\mathrm{b}}$ & $8 \pm 0.3^{d}$ & $20 \pm 2^{k}$ & $5 \pm 1^{p}$ & $14 \pm 2.6^{9}$ & $4.9 \pm 1.2^{p}$ & $9.3 \pm 0.58^{c}$ & $5 \pm 1^{p}$ & $10 \pm 3^{x}$ & $5 \pm 1^{p}$ & $8.1 \pm 2^{y}$ \\
\hline
\end{tabular}

Values are mean of three replicates $\pm S D$, Different letters in the same rows indicate significant differences in values among different treatments

Table 3: IR spectra along with their assignments in the shoot samples of experimental plants grown on control and crude oil contaminated soils

\begin{tabular}{|c|c|c|}
\hline $\begin{array}{l}\text { Bands and } \\
\text { Peaks }\left(\mathrm{cm}^{-1}\right)\end{array}$ & Assignments & Samples \\
\hline $3700-3100$ & $\mathrm{O}-\mathrm{H}$ stretching of flavonoids/phenolic compounds & $\begin{array}{l}\text { Present in all samples, More intense in the plant samples of contaminated } \\
\text { soils except Xanthium }\end{array}$ \\
\hline 2920.22 & $\mathrm{C}-\mathrm{H}$ stretching indicating presence of alkane & Present in all samples, more intense in control plant samples \\
\hline 2360.76 & $\begin{array}{l}\mathrm{O}-\mathrm{H} \text { stretching of carboxylic acid compounds such } \\
\text { as benzoic acid }\end{array}$ & Present in all samples, highly intense in Xanthium of contaminated soils \\
\hline 2065.76 & C-C compounds representing alkenes & Present dominantly in Polygonum samples \\
\hline 1736.87 & $\mathrm{C}=\mathrm{O}$ stretching of aldehydes & Clear and intense in Ageratum samples of contaminated soils \\
\hline 1620.20 & $\begin{array}{l}\mathrm{C}=\mathrm{C} \text { stretching of alkenes such as } 1 \text {-hexadecane, } \\
\text { cyclohexane etc. }\end{array}$ & $\begin{array}{l}\text { Present in all samples, More intense in the plant samples of contaminated } \\
\text { soils except Xanthium }\end{array}$ \\
\hline 1381.03 & C-F stretching of fluoride/monoflourohexane & $\begin{array}{l}\text { Present in all samples, More sharp and intense in the plant samples of } \\
\text { contaminated soils }\end{array}$ \\
\hline 1062.87 & $\begin{array}{l}\text { C-O stretching of alcohols/ethers/esters/carboxylic } \\
\text { acids }\end{array}$ & Present in all samples, sharp and intense in control plant samples \\
\hline
\end{tabular}

organic carbon, the contaminated soil samples showed elevated level of organic carbon (Shaker et al., 2009; Chukwuma et al., 2010; Nwazue, 2011). The reduction in TOCs may be attributed to the microbial utilization of organic carbon from the soil. The present findings is agree with the previous study of Mrayyan and Battikhi (2005) who have reported up to $28 \%$ reduction in TOC level in the oil contaminated soil. It has been found that plant's exudate enhances the microbial population which in turn act on organic carbon and reduces the TOC levels during phytoremediation trials.

The initial values of total Kjeldhal nitrogen (TKN), available phosphorus (AP) and total potassium (TK) in the contaminated soil were recorded as $890 \mathrm{mg} \mathrm{kg}^{-1}, 30 \mathrm{mgkg}^{-1}$ and $272.56 \mathrm{mgkg}^{-1}$, respectively. The results showed that TKN, AP and TK values in soil samples decreased significantly by end of the experimental trials irrespective of the experimental plant species used in the experiment. The decrease in TKN values in the treated soil was found within 1.7-2.2 folds for Ageratum conyzoides, Polygonum hydropiper and Xanthium strumarium. Similarly, decrease in AP was 1.2, 2.7 and 3.5 folds in the soil samples treated with Ageratum conyzoides, Polygonum hydropiper and Xanthium strumarium, respectively. Whereas, average TK decrease was recorded 1.2 fold in the soil samples after 60 days of treatment in all the plant treated trials. It has been suggested that microbial population in the contaminated soil utilize a significant portion of the macro as well as micronutrients besides using hydrocarbons as the sole carbon source and this process become more accelerated in presence of plants. Moreover, it is also true that plants utilize major portion of the soil nutrients for their growth and metabolic activities which ultimately decreases NPK concentrations in soil (Verma et al., 2012). 


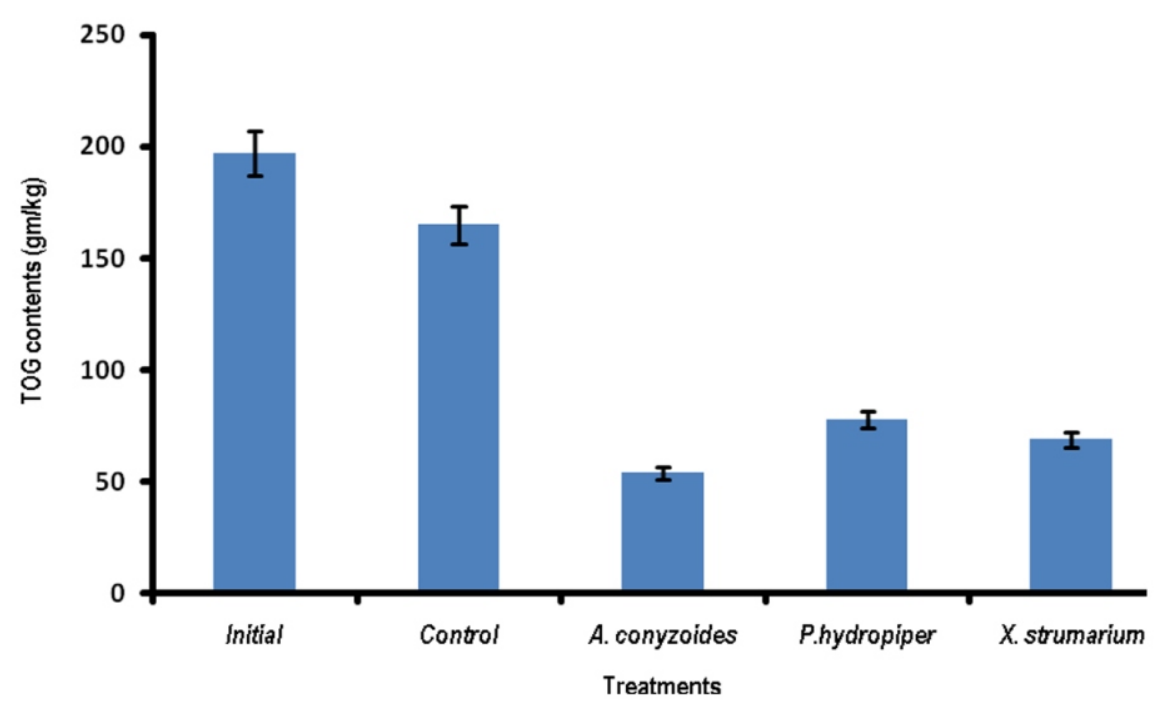

Fig. 1: Total oil and grease (TOGs) content in the crude oil contaminated soil after 60 days of treatment by Ageratum conyzoides, Polygonum hydropiper and Xanthium stromerium. Values are means of three replicates, bars indicates SD.

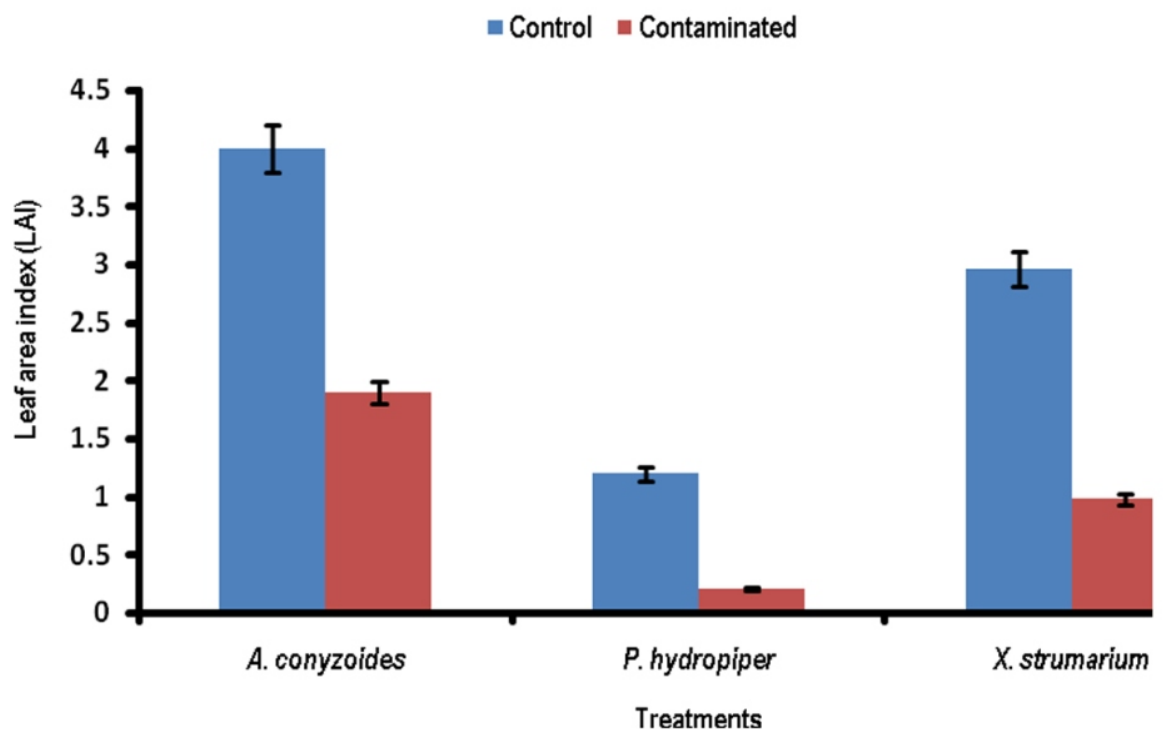

Fig. 2: Leaf area index (LAl) of Ageratum conyzoides, Polygonum hydropiper and Xanthium strumarium grown on control and oil contaminated soils. Values are means of three replicates, bars indicates SD.

Table 2 shows variations in plant growth as indicated by morphological parameters such as leaf number, shoot and root length among the studied plants grown on control and contaminated soil. The results revealed that there were significant differences in the number of leaves, shoot and root lengths in all test plants grown in control and contaminated soils. Similarly, results of the plant productivity parameters i.e., leaf area index (LAl), biomass and leaf chlorophyll contents are presented in Fig. 2, Fig. 3 and Fig. 4, respectively. The results revealed that LAI, plant biomass and chlorophyll a, chlorophyll b, total chlorophyll content of Ageratum conyzoides, Polygonum hydropiper and Xanthium strumarium grown in the control soil were significantly higher as against the same plants grown on contaminated soil. As a whole, crude oil contamination caused negative effects on both growth and productivity of the test plants, which is obvious as crude oil associated pollutants impose abiotic stress on the plants (VJ and Okunnu, 2012; Samal and Santra, 2002; Anthony, 2001; 


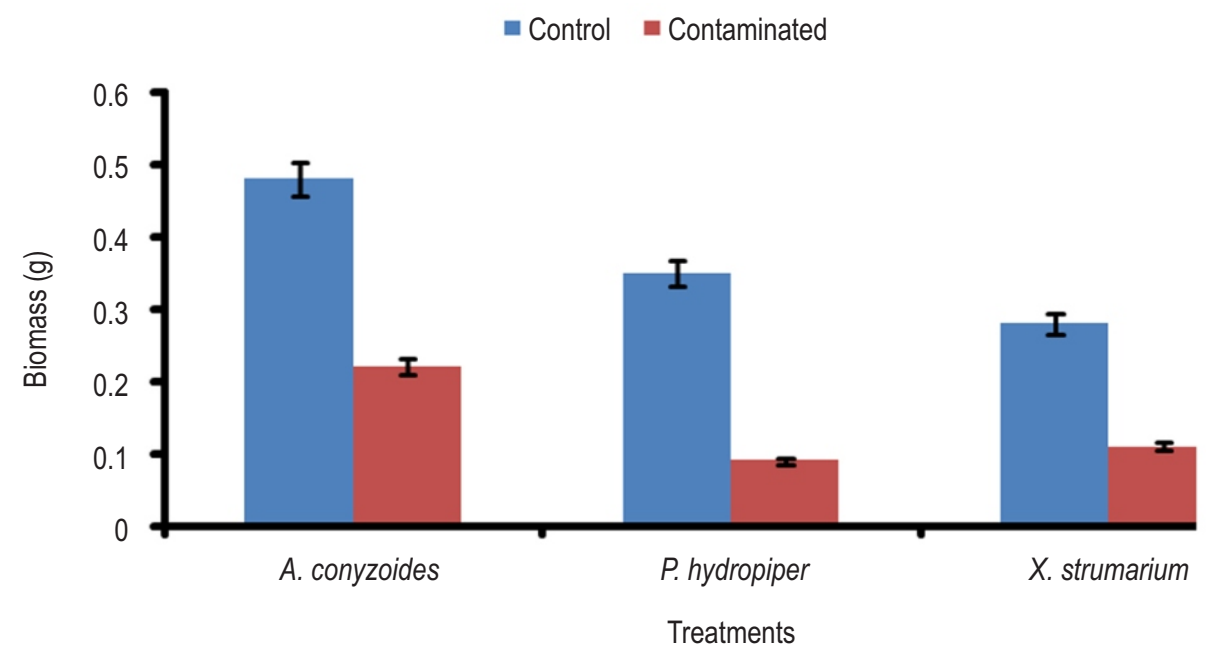

Fig. 3: Shoot and root biomass values Ageratum conyzoides, Polygonum hydropiper and Xanthium strumarium grown on control and oil contaminated soils. Values are means of three replicates, bars indicates SD.

$$
\square \text { Chl-a } \quad \text { Chl-b } \quad \text { Total Chl }
$$

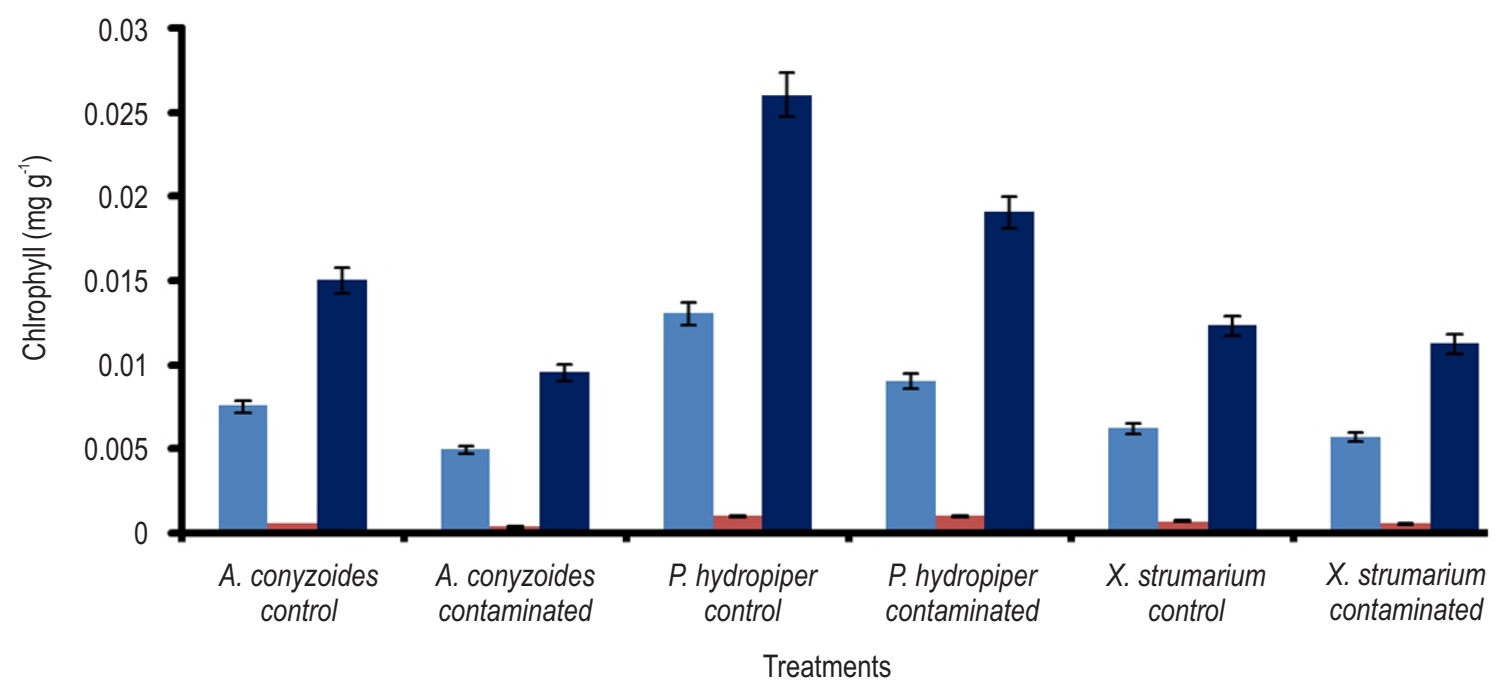

Fig. 4: Chlorophyll-a, Chlorophyll-b and total Chlorophyll contents of leaves of Ageratum conyzoides, Polygonum hydropiper and Xanthium strumarium grown on control and oil contaminated soils. Values are means of three replicates, bars indicates SD.

Ekundayo et al., 2001), thus resulting differences in growth and productivity in two contrasting habitat conditions. It has been suggested that presence of aliphatic, aromatic and high molecular weight organic compounds of crude oil inhibits the chlorophyll synthesizing enzyme and as a result chlorophyll production of the test plants was reduced (Akapo et al., 2011). This chlorophyll deficiency of plants growing in oil contaminated soil is further related with retardation in growth of plants. Moreover, water deficient condition in oil contaminated soils lead to slower photosynthesis and transpiration, and finally reduce the biomass values (Chaineau et al., 1997).

FTIR spectroscopy was conducted to understand the changes in the functional groups in the experimental plants under abiotic stress conditions induced by crude oil contaminations. The FTIR spectra was measured within the range of $500-4500 \mathrm{~cm}^{-1}$. The main absorbance bands of the IR spectra for different samples assigned for different functional groups are presented in Table 3. 


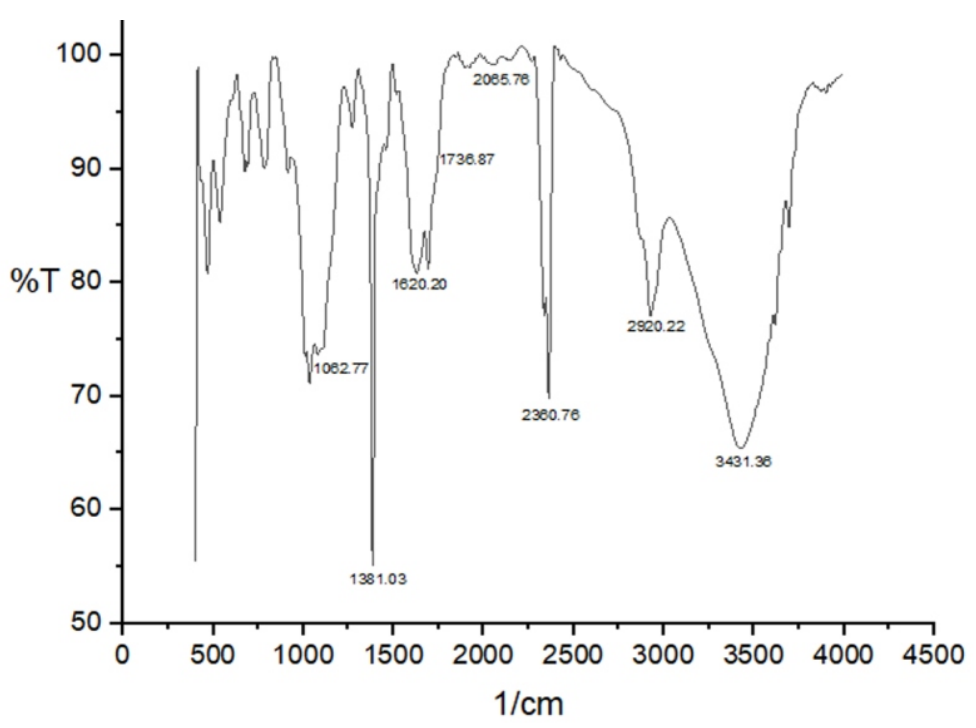

Fig. 5a: FTIR spectra of Ageratum conyzoides grown on control soil.

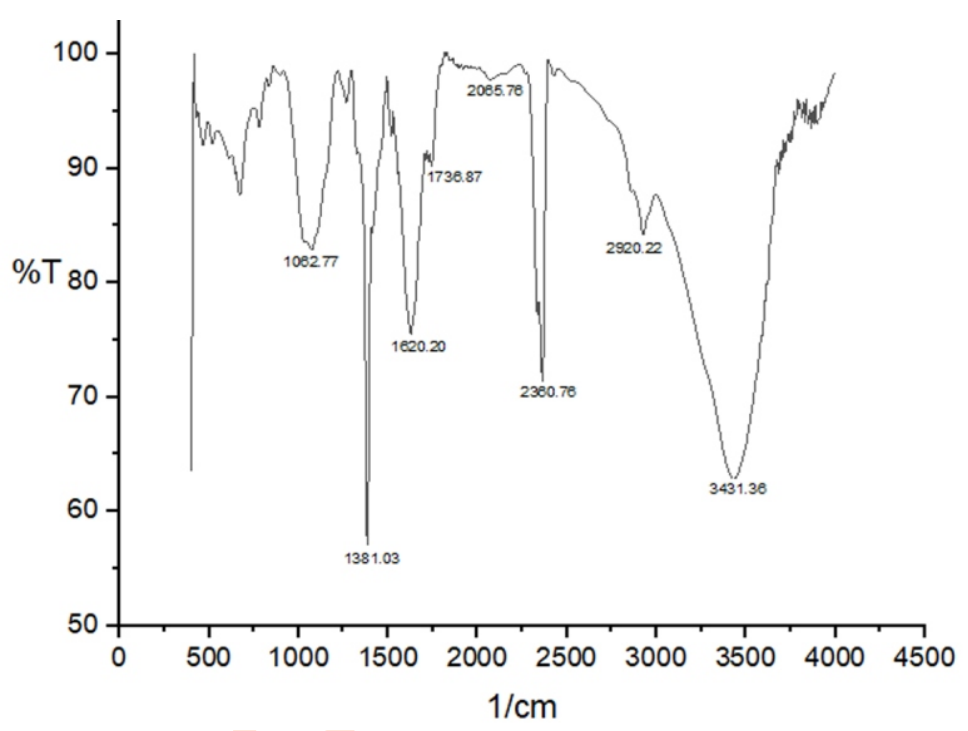

Fig. 5b: FTIR spectra of Ageratum conyzoides grown on oil contaminated soil.

The results revealed that most of the peaks and bands that represent various functional groups are common and found in the plant samples obtained from both control and contaminated soils.

However, there were variations in intensities of peak and bands between the plant samples grown in control and contaminated soils. The broad band between $37003100 \mathrm{~cm}^{-1}$ due to $\mathrm{O}-\mathrm{H}$ stretching indicated the presence of flavonoids/ phenolic compounds in all samples. The intensity of this band was higher in the plant samples of contaminated soils baring Xanthium (Table
3). On the other hand, the peak at $2920.2 \mathrm{~cm}^{-1}$ due to $\mathrm{C}-\mathrm{H}$ stretching representing aliphatic alkane was found to be highly intense in all control plant samples. Although peak at $2360.76 \mathrm{~cm}^{-1}$ (O-H stretching) for carboxylic acid compounds such as benzoic acid was found in all samples, however, but the highest intensity of peak was observed in Xanthium grown in contaminated soil. The peak at $2065.76 \mathrm{~cm}^{-1}$ representing alkenes was dominant by only in the shoot samples of Polygonum. The peak at 1736.87 $\mathrm{cm}^{-1}$ due to $\mathrm{C}=\mathrm{O}$ stretching for aldehydes was very distinct in the Ageratum shoot samples of contaminated soils whereas the peak 


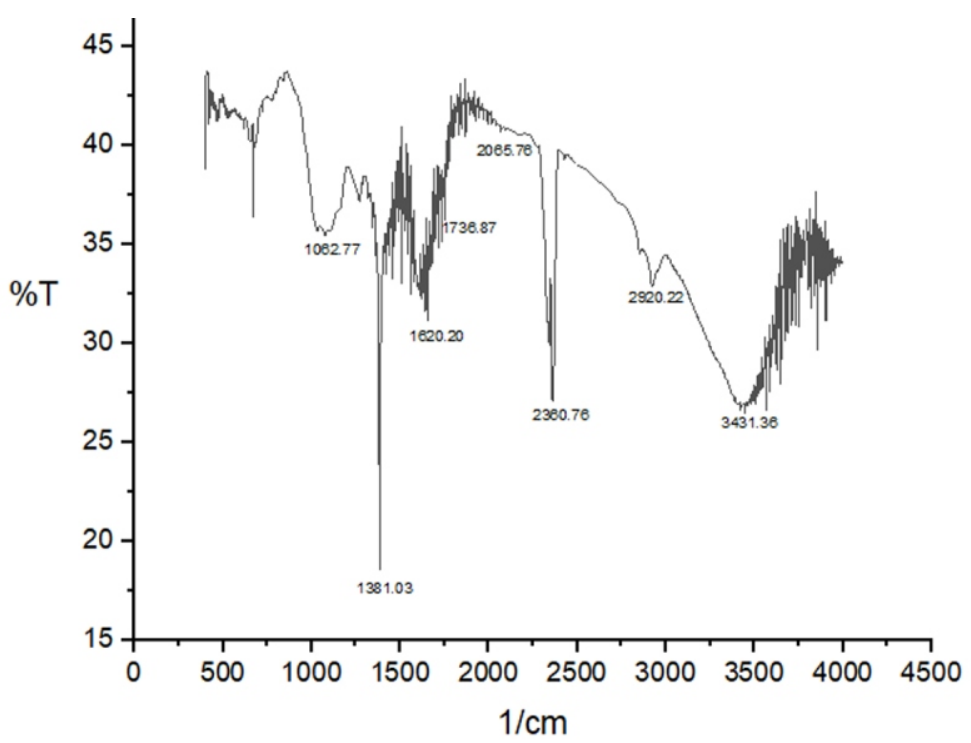

Fig. 5c: FTIR spectra of Polygonum hydropipergrown on control soil.

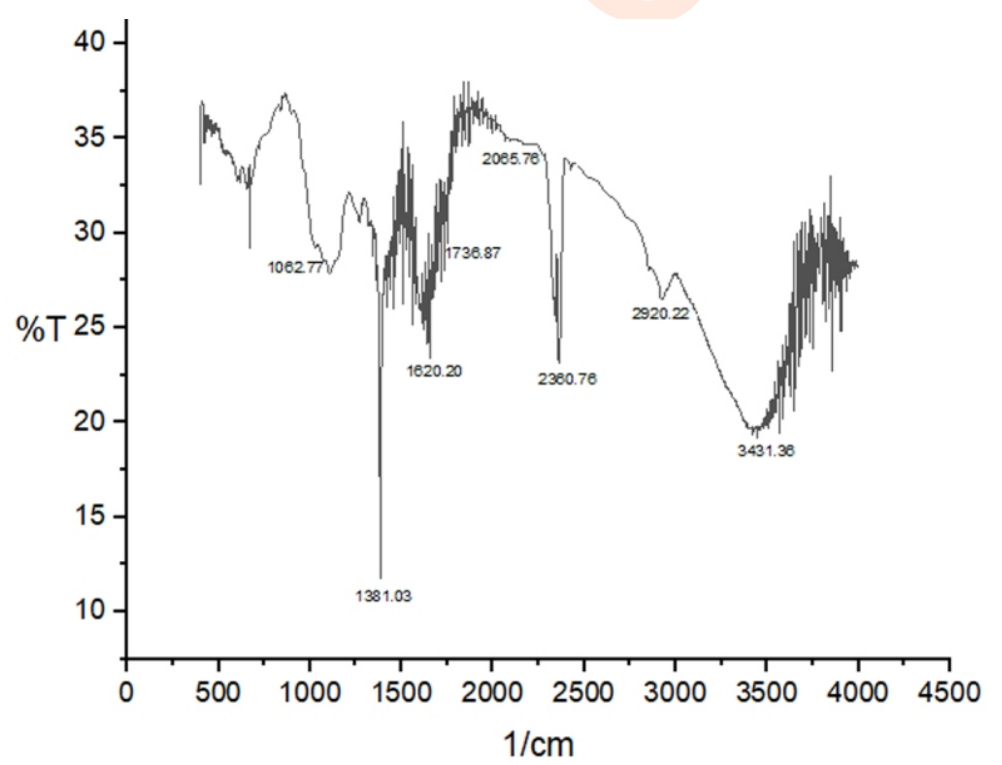

Fig. 5d: FTIR spectra of Polygonum hydropipergrown on oil contaminated soil.

at $1062.87 \mathrm{~cm}^{-1}$ due to $\mathrm{C}-\mathrm{O}$ stretching for alcohols was more prominent in all control samples. The peak at $1620.2 \mathrm{~cm}^{-1}$ due to $\mathrm{C}=\mathrm{C}$ stretching for alkenes such as 1-hexadecane and cyclohexane was found in all samples, however, peak intensity was higher in the plant samples of contaminated soils. The peak at $1381.03 \mathrm{~cm}^{-1}$ for $\mathrm{C}-\mathrm{F}$ stretching of fluoride/monoflourohexane was found to be more intense and sharp in the plant samples of contaminated soils.

As a whole the results showed both increase as well as decrease in intensities of various bands and peaks among the studied plant samples. This clearly indicates the adverse effects of crude oil on the test plants. It has been suggested that increase and/or decrease as well as shifting in bands/peaks occurs when plants are exposed to abiotic stress such as crude oil contaminations (Liu et al., 2012), which usually vary from species to species. Moreover, the increase in the intensities of peaks/ bands in the plant samples of contaminated soils may be due to uptake and metabolism of crude oil components by the experimental plants (Devatha et al., 2019). Further, various compounds such as alcohols, phenols, aliphatic hydrocarbons, carboxylic acids etc., are component of plants (Bobby et al., 


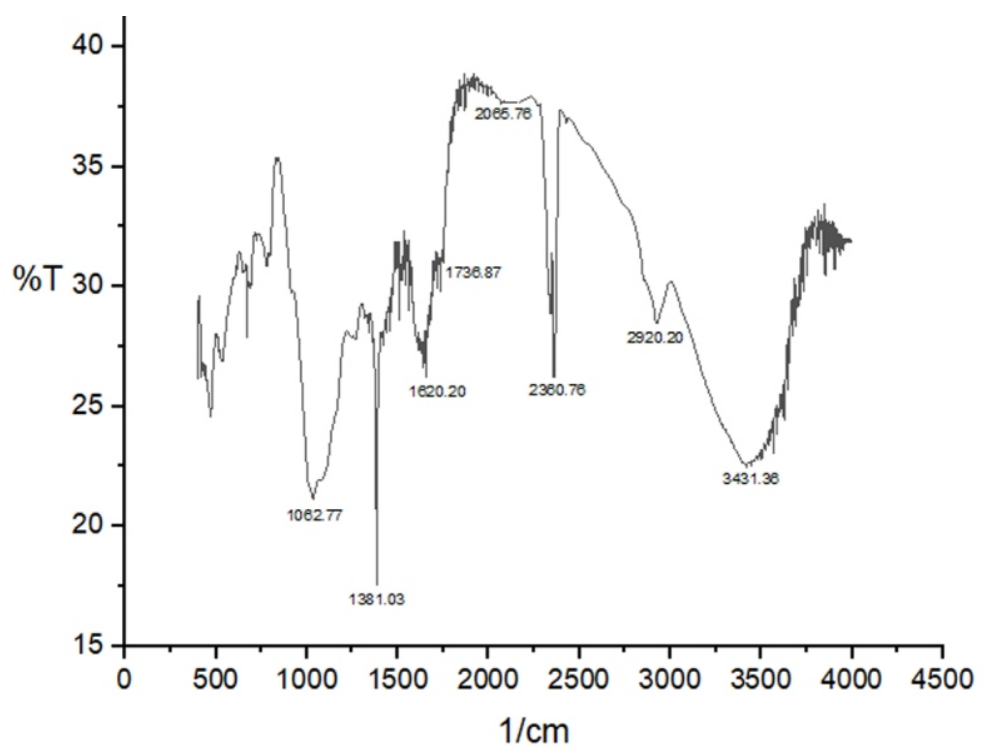

Fig. 5e: FTIR spectra of Xanthium strumarium grown on control soil.

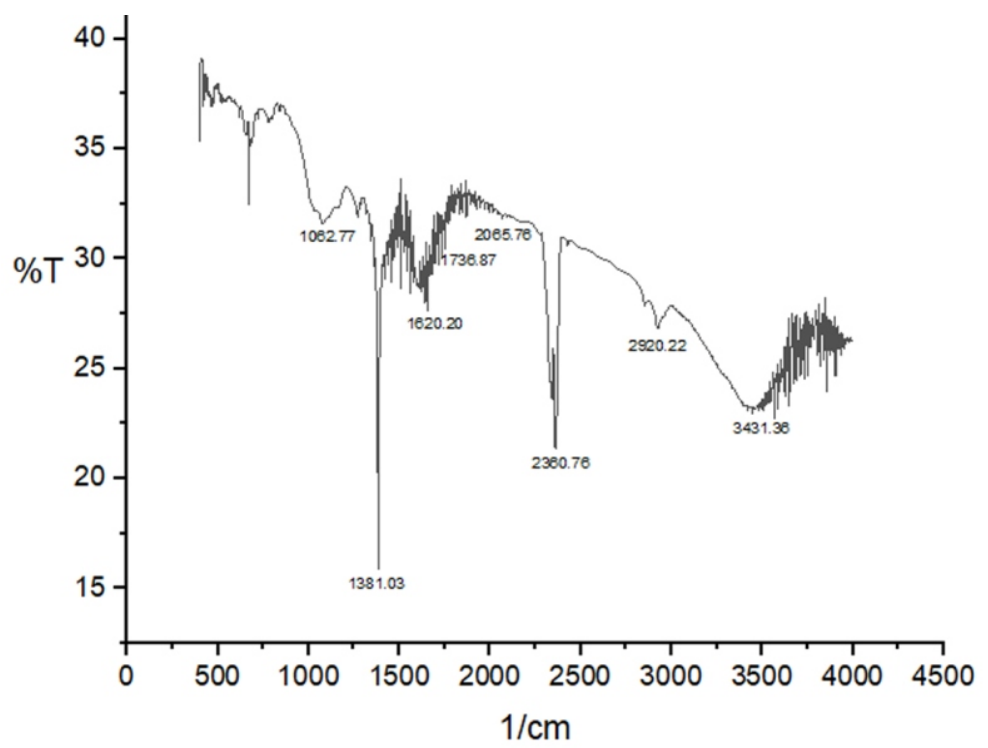

Fig. 5f: FTIR spectra of Xanthium strumarium grown on oil contaminated soil.

2012) which justify the presence of intense bands/peaks indicating the presence of these compounds in control plant samples.

In the present study, it was found that Ageratum conyzoides was the most potent herb, followed by Xanthium strumarium and Polygonum hydropiper in removal of total oil and grease from the crude oil contaminated soils. FTIR analysis clearly showed the uptake as well as metabolism of oil and grease by the experimental plants from the contaminated soil.
Nevertheless, further planned study is needed on plant- microbe synergy to understand the mechanism of oil and grease or hydrocarbons dissipation from contaminated soils.

\section{Acknowledgment}

The corresponding author is grateful to the University Grant Commission (UGC), New Delhi for funding under BSR Start-Up-Grant scheme (Grant No: F.30-386/2017/BSR). 
Add-on Information

Authors' contribution: S. Akram: Carried out the experimental works and wrote the manuscript with Hemen Deka; H. Deka: Developed the concept of this experimental works, provided laboratory facilities and guided Shaleh Akram and wrote the manuscript.

Research content: The research contents is original and has not been published elsewhere

Ethical approval: NotApplicable.

Conflict of interest: The author declares that there is no conflict of interest.

\section{Data from other sources: NotApplicable}

Consent to publish: All authors agree to publish the paper in Journal of Environmental Biology.

\section{References}

Akapo, A.A.R., S.O. Omidiji and A.A. Otitoloju: Morphological and anatomical effects of crude oil on Pistia stratiotes. The Environ., 31, 288-298 (2011)

Akpoveta, O.V., B.E. Okoh and S.A. Osakwe: Quality assessment of borehole water used in the vicinities of Benin, Edo State and Agbor, Delta State of Nigeria. Curnt. Res. Chem., 3, 62-69 (2011).

Anyika, C., Z.A. Majid, Z. Ibrahim, M.P. Zakaria and A. Yahya: The impact of biochars on sorption and biodegradation of polycyclic aromatic hydrocarbons in soils-a review. Environ. Sci. Pollut. Res., 22, 3314-3341 (2015).

Anthony, P.: Dust from walking tracks: Impacts on rainforest leaves and epiphylls. Cooperative Research Centre for Tropical Rainforest Ecology and Management, 2 (2001).

APHA-American Public Health Association: Standard methods for the examination of water and wastewater. APHA, USA (1998).

Asemoloye, M.D., S.G. Jonathan and R. Ahmad: Synergistic plantmicrobes interactions in the rhizosphere: A potential headway for the remediation of hydrocarbon polluted soils. Int. J. Phyto., 21, 71$83(2019)$.

Baruah, P., P.P. Baruah and S. Deka: Removal of hydrocarbon from crude oil contaminated soil by Cyperus brevifolius Rottb. Bull Environ. Pharmacol. Life Sci., 2,123-130 (2013).

Barua, D., J. Buragohain and S.K. Sarma: Certain physico-chemical changes in the soil brought about by contamination of crude oil in two oil fields of Assam, NE India. Pelagia Research Library. Eur. J. Exper. Biol., 1, 154-161 (2011).

Baruah, P., R.R. Saikia, P.P. Baruah and S. Deka: Effect of crude oil contamination on the chlorophyll content and morpho-anatomy of Cyperus brevifolius (Rottb.) Hassk. Environ. Sci. Pol. Res., 21, 12530-12538 (2014).

Basumatary, B., R. Saikia and S. Bordoloi: Phytoremediation of crude oil contaminated soil using nut grass, Cyperus rotundus. J. Environ. Biol., 33, 891-896 (2012a).

Basumatary, B., S. Bordoloi and H.P. Sarma: Crude oil-contaminated soil phytoremediation by using Cyperus brevifolius (Rottb.) Hassk. WaterAir Soil Poll., 223, 3373-3383 (2012b).

Bobby, M.N., E.G. Wesely and M. Johnson: FT-IR studies on the leaves of Albizia lebbeck Benth. Int. J. Pharm. Pharm. Sci., 4, 293-6 (2012).

Bordoloi, S., B. Basumatary, R. Saikia and H.C. Das: Axonopus compressus (Sw.) P. Beauv. A native grass species for phytoremediation of hydrocarbon- contaminated soil in Assam, India. J. Chem. Technol. Biotechnol., 87, 1335-1341 (2012).

Cai, Z., Q. Zhou, S. Peng and K. Li: Promoted biodegradation and microbiological effects of petroleum hydrocarbons by Impatiens balsamina L. with strong endurance. J. Hazard. Mater., 183, 731-737 (2010).

Chaineau, C.H., J.L. Morel and J. Oudot: Phytotoxicity and plant uptake of fuel oil hydrocarbons. J. Enviro. Qua., 26, 1478-1483 (1997).

Cheng, L., Y. Wang, Z. Cai, J. Liu, B. Yu and Q. Zhou: Phytoremediation of petroleum hydrocarbon-contaminated saline-alkali soil by wild ornamental Iridaceae species. Int. J. Phytorem., 19, 300-308 (2017).

Chukwuma, C.C., J.C. Ikewuchi and M.O. Monanu: Removal of hydrocarbons from crude oil contaminated agricultural soil by phytoremediation using Mariscus alternifolius and Fimbristylis ferruginea. Eur. J. Biol Res., 9, 34-44 (2019).

Chukwuma, M.C., E.T. Eshett, E.U. Onweremadu and M.A. Okon: Zinc availability in relation to selected soil properties in a crude oil polluted eutric tropofluvent. Int. J. Enviro. Sci. Tech., 7, 261-270 (2010).

Das, N. and P. Chandran: Microbial degradation of petroleum hydrocarbon contaminants: An overview. Biotec. Res. Int., 2011, 941810 (2011).

Devatha, C.P., A.V. Vishal and J.P.C. Rao: Investigation of physical and chemical characteristics on soil due to crude oil contamination and its remediation. App. Water. Sci., 9, 89 (2019).

Egharevba, I.P., E.O. Aluyor, C.O. Osagiede and N.A. Ihoeghian: Phytoremediation of crude oil polluted soil using Glycine max and Megathyrsus maximus. Nigerian Res. J. Eng. Enviro. Sci., 2, 515$523(2017)$.

Ekundayo, E.O., T.O. Emede and D.I. Osayande: Effects of crude oil spillage on growth and yield of maize (Zea mays L.) in soils of midwestern Nigeria. Plant Food. Human Nutri., 56, 313-324 (2001).

Euliss, K., C. Ho, A.P. Schwab, S. Rock and K. Banks: Greenhouse and field assessment of phytoremediation for petroleum contaminants in a riparian zone. Biores. Technol., 99, 1961-1971 (2007).

Federation, W.E. and American Public Health Association: Standard method for the examination of water and waste water. APHA. Washington, D.C., USA(2005)

Han, T., Z. Zhao, M. Bartlam and Y. Wang: Combination of biochar amendment and phytoremediation for hydrocarbon removal in petroleum-contaminated soil. Environ. Sci. Pollut. Res., 23, 21219-21228 (2016).

Hutchinson, S.L., M.K. Banks and A.P. Schwab: Phytoremediation of aged petroleum sludge: Effect of inorganic fertilizer. J. Environ. Qual., 30, 395-403 (2001).

Ikhajiagbe, B., B.O. Edegbai, G.O. Omoregie and A.M. Eweka: Assessment of the phytoreclamation of an oil-contaminated soil cultivated with Cynodon dactylon, Eleusine indica and Eragrostis tenela. Studia Universitatis Babeş-Bolyai, Biologia., LXII, 62, 43$55(2017)$.

Ikeura, H., Y. Kawasaki, E. Kaimi, J. Nishiwaki, K. Noborio and M. Tamaki: Screening of plants for phytoremediation of oilcontaminated soil. Int. J. Phytorem., 18, 460-466 (2016).

Jackson, M.L.: Soil Chemical Analysis, Pentice Hall of India Pvt. Ltd., New Delhi, India, 498, 151-154 (1973).

Kaimi, E., T. Mukaidani and M. Tamaki: Screening of twelve plant species for phytoremediation of petroleum hydrocarbon-contaminated 
soil. Plant. Produc. Sci., 10, 211-218 (2007).

Kechavarzi, C., K. Petterson, P. Leeds-Harrison, L. Ritchie and S. Ledin: Root establishment of perennial ryegrass ( $L$. perenne) in diesel contaminated subsurface soil layers. Environ. Poll., 145, 68-74 (2007).

Kirkpatrick, W.D., P.M. White Jr., D.C. Wolf, G.L. Thoma and C.M. Reynolds: Selecting plants and nitrogen rates to vegetate crude oil contaminated soil. Int. J. Phytorem., 8, 285-297 (2006).

Lai, C.H., H.C. Li and K.S. Chen: Source characterization and environment impact of open burning of rice straw residues on polycyclic aromatic hydrocarbons in agricultural county, Taiwan. J. Environ. Eng. Manage., 19, 79-88 (2009).

Liao, C., W. Xu, G. Lu, F. Deng, X. Liang, C. Guo and Z. Dang: Biosurfactant-enhanced phytoremediation of soils contaminated by crude oil using maize (Zea mays. L). Ecol. Eng., 92, 10-17 (2016).

Lin, Q. and I.A. Mendelssohn: The combined effects of phytoremediation and biostimulation in enhancing habitat restoration and oil degradation of petroleum contaminated wetlands. Eco. Eng., 10, 263-274 (1998).

Liu, R., N. Xiao, S. Wei, L. Zhao and J. An: Rhizosphere effects of PAH contaminated soil phytoremediation using a special plant named Fire Phoenix. Sci. Total Environ., 473, 350-358 (2014a).

Liu, W., J. Hou, Q. Wang, L. Ding and Y. Luo: Isolation and characterization of plant growth- promoting rhizobacteria and their effects on phytoremediation of petroleum-contaminated salinealkali soil. Chemosphere, 117, 303-308 (2014b).

Liu, R., R.N. Jadeja, Q. Zhou and Z. Liu: Treatment and remediation of petroleum-contaminated soils using selective ornamental plants. Env. Eng. Sci., 29, 494-501 (2012).

Martin, Jr, J.H., Siebert, A.J. and R.C. Loehr: Estimating oil and grease content of petroleum- contaminated soil. J. Environ. Enginee., 117, 291-299 (1991).

Merkl, N., R. Schultze-Kraft and C. Infante: Phytoremediation in the Tropics-The effect of crude oil on the growth of tropical plants. Biorem. J., 8,177-184 (2004).

Mrayyan, B. and M.N. Battikhi: Biodegradation of total organic carbons (TOC) in Jordanian petroleum sludge. J. Haza. Mat., 120, 127-134 (2005).

Nwazue, N.R.: The effect of crude oil spill on the ascorbic acid content of some selected vegetable species: Spinacia oleracea, Solanum melongena and Talinum triangulare in an oil polluted soil. Pak. J. Nutr., 10, 274-281 (2011).

Osuji, L.C. and I. Nwoye: An appraisal of the impact of petroleum hydrocarbons on soil fertility: the Owaza experience. African J. Agri. Res., 2, 318-324 (2007).

Oyem, I.L.R. and I.L. Oyem: Effects of crude oil spillage on soil physicochemical properties in Ugborodo community. Int. J. Mod. Eng. Res., 3, 3336-3342 (2013).

Patowary, K., M.C. Kalita and S. Deka: Degradation of polycyclic aromatic hydrocarbons (PAHs) employing biosurfactant producing Pseudomonas aeruginosa KS3. Indian J. Biotechnol., 14, 208-215 (2015).

Pavia, D., G.M. Lampman, G.S. Kriz and J.A. Vyvyan: Introduction to Spectroscopy, Cengage Learning. Ainara López Maestresalas, 153, 752 (2008).

Peng, S., Q. Zhou, Z. Cai and Z. Zhang: Phytoremediation of petroleum contaminated soils by Mirabilis jalapa L. in a greenhouse plot experiment. J. Haza. Mat., 168, 1490-1496 (2009).

Rehman, K., A. Imran, I. Amin and M. Afzal: Inoculation with bacteria in floating treatment wetlands positively modulates the phytoremediation of oil field wastewater. J. Haza. Mat., 349, 242251 (2018).

Samal, A.C. and S.C. Santra:Air quality of Kalyani township (Nadia, West Bengal) and its impact on surrounding vegetation. Ind. J. Enviro. Hlth., 44, 71-76 (2002).

Scott, S.L. and Y.M. Nelson: Biodegradability and toxicity of hydrocarbon leachate from land treatment units. Civil Enviro. Eng., 94, 8 pages (2004).

Shaker, G.A., B.A. Ali and H.H. Ali: The impact of ascending levels of crude oil pollution on growth of olive (Olea europaea Linn) seedlings. Ibn AL-Haitham J. Pure. App. Sci., 22, 17-23 (2009).

Shehzadi, M., K. Fatima, A. Imran, M.S. Mirza, Q.M. Khan and M. Afzal: Ecology of bacterial endophytes associated with wetland plants growing in textile effluent for pollutant- degradation and plant growth-promotion potentials. Plant Biosy., 150, 1261-1270 (2016).

Singh, R.S., A.S. Raghubanshi and J.S. Singh: Nitrogen-mineralization in dry tropical savanna: Effects of burning and grazing. Soil. Bio. Biochem., 23, 269-273 (1991).

Urum, K., S. Grigson, T. Pekdemir and S. McMenamy: A comparison of the efficiency of different surfactants for removal of crude oil from contaminated soils. Chemosphere, 62, 1403-1410 (2006).

Villalobos, M., A.P. Avila-Forcada and M.E. Gutierrez-Ruiz: An improve gravimetric method to determine total petroleum hydrocarbons in contaminated soils. WaterAir Soil Pollut., 194, 151-161 (2008).

Verma, G., R.P. Sharma, S.P. Sharma, S.K. Subehia and S. Shambhavi: Changes in soil fertility status of maize-wheat system due to longterm use of chemical fertilizers and amendments in an alfisol. Plant. Soil. Env., 58, 529-533 (2012).

VJ, O. and O.O. Okunnu: Effects of simulated crude oil pollution on the growth of Manihot esculenta Crantz. Ind. J. Sci., 1,116-119 (2012).

Walkey, A. and C.A. Black: Critical examination of rapid method of determining organic carbon in soil. J. Soil. Sci., 63, 251-254 (1974).

Wei, Y., Y. Wang, J. Han, M. Cai, K. Zhu and Q. Wang: Analysis of water retention characteristics of oil-polluted earthy materials with different textures based on van Genuchten model. J. Soil. Sed., $19,373-380$ (2019). 